\title{
Facing War: On Veterans, Wounds, and Vulnerability in Danish Public Discourse and Contemporary Art
}

\author{
Ann-Katrine Schmidt Nielsen
}

\section{INTRODUCTION}

In the controversial portrait series RAMT. 15 danske politikere [HIT. 15 Danish politicians; my translation] (2011), artist, activist and pilot Simone Aaberg Kærn transposes typical facial war wounds onto the portraits of 15 Danish politicians. The depictions all imitate traditional portraits, they are drawn in neutral colours-and they are all extremely gory: jaws are blown off, blood flows and the former Prime Minister is missing an eye. Kærn has previously employed the portrait to investigate the violence of war. In the series with the resounding title RAMT. Sarrede danske soldater $i$ Helmand [HIT. Wounded Danish soldiers in Helmand; my translation] (2010), wounded soldiers are portrayed in a manner similar to the politicians. Although the title of this series indicates that the depicted soldiers are Danish, the caption reveals that the faces are, in fact, those of wounded

\section{A.-K. S. Nielsen $(\bowtie)$}

Aarhus University, Aarhus, Denmark

e-mail: norasn@cc.au.dk

(C) The Author(s) 2020

A. M. Dancus et al. (eds.),

Vulnerability in Scandinavian Art and Culture, https://doi.org/10.1007/978-3-030-37382-5_13 
Afghans that have undergone a conspicuous 'Nordification'. Read together, these two series present us with multiple, layered faces and 'travelling' war wounds that inevitably conjure up the disturbing questions: Where do these wounds originate? Whose faces have seen such violence?

Kxrn is a much-debated Danish artist. Most of her work revolves around contemporary Danish warfare, and she has visited remote war zones on several occasions. In the 'aero-feminist' film project Smiling in a War Zone (2006), Kærn goes on a solo flight from Denmark to Kabul and, in 2011, she stayed in Libya during the revolt and incipient civil war. Nationally, she is best-known for her controversial, official portrait of resigned Prime Minister Anders Fogh Rasmussen and the large-scale triptych Batalje [Skirmish] (2016), which depicts the war in Libya. The Museum of National History and the Danish Defence commissioned this piece as an official battle painting, but rejected it before its actual realization. In the words of Major General Per Ludvigsen, the preliminary sketch did not convey 'the actually quite happy story' (Sangild 2016, my translation) of the Libyan war. Hence, Kxrn's oeuvre is large, interesting and controversial. However, this chapter focuses on the two entangled RAMT series, since they tangibly bring to the fore the wounding and vulnerability of bodies in Danish warfare. This issue has proved central in Denmark's transformation from a small, pacifist state to a warring coalition partner in the post-Cold War era (Sørensen 2015).

This chapter addresses Judith Butler's adaptation of the Levinasian face of the Other and Jacques Derrida's hauntology, and argues that the depictions of the wounded faces of Danish politicians and soldiers may, paradoxically, convey a haunting encounter with the suffering, wounded Other, the non-Western victim, of Danish warfare. This is of crucial pertinence in the Danish media and political contexts, which are dominated by the hypervisibility of the wounded veteran. The intense focus on the wounded Danish body, the chapter argues, serves as a means of promoting a narrative of unidirectional violence and erasing the vulnerable, wounded Other from public view-an act of erasure that Kærn's layered faces and travelling war wounds complicates. The chapter outlines the public discourse on the wounded veteran through the Prime Ministers' speeches on 5 September, the National Flag-flying Day for Deployed Personnel, and the central series of articles Hjem fra krigen [Home from the War; my translation], published by the national Danish newspaper Jyllands-Posten. ${ }^{1}$ Representing national media and domestic 
politics, these are privileged sites in the public production of the discourse on the wounded veteran. The chapter proceeds to analyse Kærn's portrait series through a palimpsestic mode of reading uncovering traces, engaging absent-presences of hauntings and interpreting the 'complex layering of diverse texts' (McLoughlin 2018, p. 174). ${ }^{2}$

\section{SPEAKING OF WAR-SEPTEMBER 5TH}

On a bright, sunny afternoon in the early autumn of 2018, thenDanish Prime Minister Lars Løkke Rasmussen gave the annual speech at the national event honouring and commemorating all Danish personnel deployed since 1948. Danish flags waved from the top of the parliament building against a clear blue sky, long rows of uniformed soldiers were ranked in front of the Prime Minister, and the Danish Crown Princess resided as a royal representative in the midst of it all.

Since 2009, 5 September has been a national flag-flying day, when Denmark pays its respects to all those who have been deployed in areas of conflict. ${ }^{3}$ The flag-flying day is part of an extensive, ongoing national effort to assume a new role as a warring nation, and to negotiate the concomitant political and sociocultural remilitarization (Christensen 2015; see also Sørensen and Pedersen 2012, on homecoming parades). Since the end of the 1980s, Danish foreign policies have been increasingly (re)militarized. During the 1990s and 2000s, Danish troops were deployed in military missions involving actual combat situations for the first time in over a century (Wivel 2013; Sørensen 2017; Lidegaard 2018). However, the human, societal and cultural consequences of this thorough remilitarization did not attract significant national attention until around 2008 (Pedersen 2017) and, in 2010-almost a decade into Denmark's participation in the Afghanistan war-the liberal-conservative government presented the first Danish veteran policy.

In 2010, the media directed immense attention on the veterans. The central series of articles, Hjem fra krigen, which later won the prestigious Cavling Prize award, ran throughout the year in the national newspaper Jyllands-Posten, investigating the difficult lives of physically and psychologically wounded veterans in Denmark. This is a two-part series: one devoted to the physical wounds, and the other to the psychological wounds of Danish warfare. In the article that introduces the second part of the series, the problem is presented in this way: 'They went away to 
help others. Today they are the ones who need help and society's knowledge about veterans' welfare is limited' (Pedersen and Westh 2010, my translation). The veterans' problems and a criticism of the failing welfare state were immediately picked up by other media. Headlines such as 'The mental minefield' (Jyllands-Posten, 2010, 20 June), 'Helpless war veterans in the woods' (Ekstra Bladet 2010, 21 June), and 'Soldiers wait in line to get help' (Jyllands-Posten 2010, 20 December) abounded in national newspapers. ${ }^{4}$ As such, the veteran as somebody either physically or psychologically wounded by war gained extensive national visibility in 2010 .

Since 2010, a great deal of the ignorance cited as the motive behind the article series Hjem fra krigen has been eliminated. National surveys and research have shown that no more than $30 \%$ of a veteran population deployed in the period 1992-2009 report that they have been either repatriated, wounded or self-evaluate as injured (physically or psychologically) due to deployment (SFI 2012). Other research results 'normalize' veteran suicide rates (Veterancentret 2016). This attests to the fact that the larger part of Danish veterans return home without permanent wounds and scars. However, to this day, the notion of the veteran as marked and vulnerable prevails in contemporary media discourses (e.g. Pedersen 2017).

Lars Løkke Rasmussen's address to the veterans on 5 September 2018 was consistent with the intense focus on the wounds of war in contemporary Denmark:

Dear soldiers and dear veterans. Denmark owes you many thanks. [...] To return home is not always easy. Nobody, who has been deployed, returns home unaffected. Many return stronger. But some return with serious scars on both body and mind. I was reminded of this this morning when I cycled from Høvelte to Copenhagen together with veterans who are physically and psychologically wounded. It was the last stage of the Ride 4 Rehab race. ${ }^{5}$ Incredibly strong people. Who fight for a decent life. But who have been severely marked by their contribution to Denmark. (Rasmussen 2018, my translation)

While the Prime Minister does outline two alternatives-the war may either strengthen or scar the soldier-the greater part of the address focuses on the difficulty of homecomings, and is concluded by the introduction of a new bill granting economic compensation to veterans wounded before August 1996. Hence, notions of violence and trauma, 
struggle and wounds, resonate in the Prime Minister's speech, and stick to the veteran body (Ahmed 2014). His use of the phrase, 'scars on body and mind' is instructive and generic - the phrase occurs in five of the eight 5 September speeches. As such, the hypervisibility of the Danish body wounded by war may lead us to infer that the figure of the wounded veteran plays a central role in the process of negotiating the meanings of Danish (re)militarization.

\section{Framing Wounds}

In her thorough discussion of the flag-flying day, The Figure of the Soldier: Discourses of Indisputability and Heroism in a New Danish Commemorative Practice, historian Tea Dahl Christensen (2015) also notes the tendency to present veterans as a strong, 'yet also a distinct and vulnerable group with special needs to which society is obliged to attend' (p. 358). Her focus is the discursive construction of the soldier figure in the official speeches on 5 September 2013. However, she also touches on the veteran figure, as the hypervisibility of the vulnerable veteran challenges the discursive construction of 'the soldier as a peace-loving figure waging ethical warfare' (Christensen 2015, p. 360). She concludes that, by being a wounded and vulnerable body, the veteran brings violence back into discourses on contemporary warfare and soldiering-a violence that the official representatives of the Danish state have tried to erase and mute through a humanitarian discourse of contemporary warfare as nonviolent and just: 'the wounded veterans distort this image by also being wounded, vulnerable subjects in a mission that admittedly is a violent war' (Christensen 2015, p. 360).

Christensen is right when she contends that the wounded body of the veteran brings violence back into discursive view. However, something does not quite add up. If the wounded veteran reveals 'cracks in the image of the soldier as strong and as a non-combatant' (Christensen 2015 , p. 359), as proposed by the official speakers on the flag-flying day, then why do these very same speakers repeatedly return to this warwounded body? Why is the mention of 'scars on body and mind' by now a generic element of the Prime Minister's 5 September speech? Why has the wounded veteran body-an indexical trace of war's violence-become a fixture in Danish media and political discourse on contemporary wars? I suggest that, rather than merely distorting ideas of non-violent warfare, the hypervisibility of the wounded veteran body has become a means of 
framing violence in ways that promote a narrative of unidirectional violence, and bestow visibility on some victims of war, while erasing others from view in the eyes of the Danish public.

In Precarious Life (2004) and Frames of War (2009), Judith Butler engages with the framing of vulnerability and violence. 'Framing' refers to the workings of normative schemes in the production of some lives-and not others-as valuable, vulnerable human subjects (Butler 2009, pp. 2$5)$. She asks, for example, '[h] ow do our cultural frames for thinking the human set limits on the kind of losses we can avow as loss?' (Butler 2006, p. 32), and investigates vulnerability as both a shared human bodily condition and a differentially distributed feature marking some lives as less alive, less 'grievable', and more disposable than others. While 'the fundamental sociality of embodied life' (Butler 2006, p. 28) means that the sustenance of our lives is always dependent on and in the hands of others (Butler 2009, p. 14), cultural, discursive and visual frames limit our apprehension of this shared vulnerability. Thus, some lives are excluded, muted, or not even perceptible as living in the first place:

These norms work to give face and to efface. [...] There are ways of framing that will bring the human into view in its frailty and precariousness, that will allow us to stand for the value and dignity of human life, to react with outrage when lives are degraded or eviscerated without regard for their value as lives. And then there are frames that foreclose responsiveness, where this activity of foreclosure is effectively and repeatedly performed by the frame itself-its own negative action, as it were, toward what will not be explicitly represented. (Butler 2009, p. 77)

The cited preoccupation with the face-of giving face and effacingstems from Butler's adaptation of the Levinasian notion of 'the face of the Other'. According to Levinas, the face of the Other confronts me with an absolute otherness that I can never fully know, fix into identity, or collapse into sameness (Levinas 1996, pp. 190-192; Butler 2006, pp. 145-146). Encountering this Other face to face as a vulnerable, suffering, defenceless human being makes a fundamental ethical claim on me to apprehend the common human vulnerability, and to respond to it with non-violence (Levinas 1996, p. 195). For Levinas, the true ethical encounter with the vulnerable Other must be a face-to-face encounter, as all attempts at representation are forms of capture or fixation that fail the unrepresentability and the radical otherness of the Other (Levinas 1996, pp. 194-196; 
Butler 2006, p. 145). However, as Butler's cultural analysis is concerned with how the suffering of the distant Other in contemporary conflict and warfare may come into public view, she suggests that representation may, indeed, paradoxically, give face to the Other, convey the vulnerability and humanity of the distant Other, if it admits to its fundamental failure:

For representation to convey the human, then, representation must not only fail, but it must show its failure. There is something unrepresentable that we nevertheless seek to represent, and that paradox must be retained in the representation we give. (Butler 2006, p. 144)

Hence, for representation to convey a sense of the vulnerability and humanity of the Other, it must openly and knowingly admit to the incompleteness and failure of such representation and, thus, point beyond itself (Butler 2006, p. 150). We can never grasp and represent the Other as a human being in its absolute otherness-representation always captures and tames, excludes and frames. However, at the same time, Butler contends, we must never cease trying to represent in a way that is more sensitive to the cries and the face of the suffering Other: "We would have to interrogate the emergence and vanishing of the human at the limits of what we can know, what we can hear, what we can see, what we can sense' (Butler 2006, p. 151).

Returning to the wounded veteran in Danish media and political discourse, it becomes clear how the wounded veteran is the emblem of war's violent reality, whereas the faces and agonies of other bodies, the nonWestern victims of warfare, are effaced altogether. Anthropologist Birgitte Refslund Sørensen comments along the lines of Butler's thinking on the hypervisibility of the violated veteran in contemporary Denmark:

In Denmark, portraits of all dead and most severely injured soldiers have been published in newspapers, books, and online [...] In contrast, dead enemies and civilian casualties are not even mentioned by numbers, officially due to practical obstacles or strategic considerations but nevertheless suggesting that these are lives of lesser worth. (Sørensen 2015, p. 233)

As such, the differential distribution of visibility, wounds and vulnerability creates a narrative not of non-violence, but of unidirectional violence: as the faces and cries of wounded, vulnerable, dying Others are erased and excluded from public view, the veteran becomes visible as 
the sole victim of war's violent reality. Hence, the violence of war is admitted visibility in the Danish public-however, only when this violence is directed at the soldier's body. This insistence on the vulnerability of Danish bodies is paradoxical and in contrast to, for example, American attempts to keep (coffins of) deceased soldiers from public view (e.g. Butler 2006; Mortensen 2008). However, crucially, it works to erase the violence perpetrated by the veteran soldier directed at a vulnerable Other. The wounded, victimized veteran does not also occupy the discursive position of the violent perpetrator. Hence, the hypervisible war wounds of veterans in the Danish public works to exclude from discursive view the agonies of the wounded, vulnerable, non-Western Other of contemporary warfare, and establish a narrative of unidirectional violence directed at passive, victimized, self-sacrificing soldiers' bodies.

This discursive employment of the wounded veteran ultimately sustains the Danish war effort in two interlinked ways: (i) by framing violence as unidirectional, the war effort seems acceptable-perhaps even 'humanitarian'- to a Danish population until recently considering itself by and large pacifist (Sørensen 2015); (ii) by focusing on the wounded Danish body, the enemy Other is positioned as the sole aggressor and evildoer of war; he is the active agent of violent acts that wound Danish soldiers. Paradoxically, for this violence to end, the aggressive, violent enemy has to be extinguished. Thus, the figure of the wounded veteran reinforces the righteousness of warfare. ${ }^{6}$ As such, the opposition between wounded veteran and enemy aggressor also taps into and re-enhances the dichotomous moral structure of contemporary coalitional warfare promoted by, for example, George Bush and former Danish Prime Minister Anders Fogh Rasmussen: 'Either you're with us, or you're with the terrorists' (Butler 2006, p. 2).

Hence, Kærn's portrait series interfere in a media and political context characterized by an overwhelming focus on the agonies and cries of the national war victim, the Danish veteran, and the complete invisibility, the effective effacement of the Other, the Afghan, Iraqi, Libyan and other victim of war. In the following sections, I will trace the multiple layers of Kærn's portraits in order to analyse how this interference plays with the in/visibilities of vulnerable bodies, and may lead us to encounter the face of the Other, as well as to reflect on the framing of wounded faces. 


\section{Wounding Politicians-RAMT II}

You are looking at a neatly drawn portrait, coloured pencil on brown cartridge paper (Rosenvinge and Villemoes 2013). The colours are neutral, subdued and a little washed out: shades of brown, grey, white, beigeyrose. The medium close-up framing portrays the upper torso and the face against a neutral background. The depicted Prime Minister wears a suit and a tie. This is a standard portrait of a politician, a white Western man in power.

However, the Prime Minister's left eye is missing. A bloody crater and some sort of indefinable white matter (goo? bone? brain?) has replaced it. Crimson streams of blood run down his cheek and spill onto the white shirt and the bluish tie. The jacket, with the yellow ribbon on the lapel indicating his support of deployed soldiers, is neither torn nor tainted. The Prime Minister stares off into the distance with a dreamy but determined look on his face, seemingly unaffected by the streaming blood, the gore, and the gaping facial wound.

Fifteen similar portraits comprise the RAMT. 15 danske politikere series, in which Kxrn depicts the entire range of changing Danish Prime Ministers, Foreign Ministers and Defence Ministers from the mid-1990s and throughout the 2000s. Hence, these are the men and women involved in the political decisions leading to Danish participation in remote, coalitional warfare. The depictions all imitate the form of traditionally drawn portraits, the colours are the same neutral tones, and they are framed in similar ways - and they are all gory. Former Foreign Minister Mogens Lykketoft's jaw is gone, bits of his tongue are visible in the open bleeding mouth, and pieces of flesh hang from his cheeks; former Prime Minister Helle Thorning-Schmidt bleeds from the nose and the eyes, her mascara is smudged and blood streams from two deep (lethal?) holes in her forehead; former Defence Minister Søren Gade's cheek has been blown off, his left eye is bruised and swollen, and the cheekbone is laid bare. Yet, they do not seem to suffer any excruciating pain; they all keep up appearances.

The portrait series was part of the 2013 group exhibition Krig, kunst og Danmark [War, Art and Denmark; my translation] at Holstebro Museum. At the time, Kærn was already a controversial artist, as she had painted the abovementioned official portrait of resigned Prime Minister Anders Fogh Rasmussen in 2010. However, RAMT tapped into 
and resonated with contemporary discussions about freedom of expression and visual arts ignited in 2005 by the so-called 'Muhammed drawings', and increasing public anxieties about impending terrorist attacks against Danish democracy. In democratic societies, violence-even if symbolic-against elected politicians is the ultimate transgressive act. This had already been shown to be the case in Denmark 10 years earlier, when two left-wing activists threw red paint at then-Prime Minister Anders Fogh Rasmussen and Foreign Minister Per Stig Møller while screaming 'You have blood on your hands'. This protest against the Iraq war put the activists in jail for three and four months each, and was widely condemned (Politiken 2015, January 6). As such, Kærn's series-which applies the same logic of transgression, albeit in a different medium and genre, and for different ends-also provoked media debate when it appeared. According to Kærn, the portraits were meant to cause a stir that would lead the Danish public to discuss and reflect on the reality and routinization of Danish warfare (Information 2013, March 20). However, contrary to intentions, the actual debate seemed to reignite arguments from the Muhammed crisis regarding (artistic) freedom of expression, (selfcensorship, media, power and the depiction of faces, and was dominated by a rather paradoxical indignation at the unsolicited 'portrayal' of the Danish politicians. Former Foreign Minister Per Stig Møller, for example, stated that the artist was free to depict his face in any manner, thus subscribing to an unnegotiable notion of absolute freedom of expressionhowever, significantly, he added that the portraits were 'almost' a defence of terrorists, and 'an attack on us [politicians], who tried to stop terrorism' (Per Stig Møller in Berlingske, 12 March 2013, my translation).

Indeed, at first glance, the transgressive gesture stands out and makes the aesthetic logic of the portraits seem rather straightforward: Danish politicians in charge of the military missions abroad are aggressively attacked and positioned at the other, receiving end of violence. Hence, the portraits apply a technique of wounding in order to visualize moral responsibility, and to make present the absent and often invisible effects of remote warfare. Art historian Jacob Wamberg has called the series an 'act of symbolic terrorism' (Information, 20 March 2013; see also Juergensmeyer 2003). By making the politicians the target of war's violent reality, they are in a very concrete and tangible way faced with, and held responsible for, the decisions they made while in office. A logic of reciprocity seems to be the concept of the wounding; the command 'do unto others as you would have them do unto you' in the most literal 
sense. However, the portraits are more than mere finger-pointing and blaming of the politicians. They have a greater potential, and cause a more profound disturbance than, for example, the paint-throwing incident. This has to do with the distribution of power and responsibility in each case. Whereas the paint-throwing established a clear-cut difference between the leftist activists and the liberal-conservative government, pacifists and warmongers, innocent and despicable, good and bad, and placed sole responsibility in the 'bloodied' hands of the Foreign Minister and the Prime Minister, Kærn's portraits are murkier, and question such clear-cut templates of responsibility through notions of democracy, complicity and political representation.

Kxrn's portrait series hold no single person accountable: the politicians depicted are many, and each has been part of democratically elected governments. Thus, the act of wounding and assigning responsibility is directed not only at them, but also at the entirety of Danish society, and voters as such (Rosenvinge and Villemoes 2013). By way of juxtaposition, the portrait series attest to an insistence on the collective political responsibility underlying contemporary Danish warfare: while seven of the portraits depict ministers from the liberal-conservative governments of the 2000s, the other eight portraits depict the Social Democrats, Social-Liberals and Socialists, who were in power throughout most of the 1990s and from 2011-2015. Hence, the 15 politicians represent a broad range of the political spectrum. Kxrn thereby points to the fact that Danish warfare has been an established political practice for more than two decades, conducted by several different democratically elected governments. None of the then-major political parties may be absolved of responsibility and, as Kærn strikingly states, at some point in time every Danish citizen has probably voted for, or sympathized with, one of the 'wounded', responsible politicians and/or parties (Rosenvinge and Villemoes 2013). ${ }^{7}$ Hence, the sheer number of politicians depicted underscores not only the duration of Danish involvement in contemporary warfare, but also the democratic backdrop to this practice. Through a technique of 'wounding', Kxrn gestures at the democratic complicity and political preconditions of contemporary Danish warfare.

The intended message of the portrait series seems readily legible: we all have a share in the violence and wounds of contemporary warfare, and must reflect on this. The series speaks to us of the complicity of political representation, the potentially violent consequences of democratic decisions, and the collective responsibilities of voters and politicians alike, 
through the wounded faces of Danish ministers. However, there is something more at stake, something that draws our eyes back to the portraits again and again, something that haunts us: it is the fascination of the gore, the ambiguity of disgust, and the transgressive aesthetics of the gaping wound and missing jaw in Mogens Lykketoft's face; it is the enigma of Søren Gade's incipient smile, of Lars Løkke Rasmussen's dreamy but determined stare, and of their seeming unaffectedness by the streaming blood; and it is the zombielike gaze of Helle Thorning-Schmidt, the uncertainty of whether she is dead or alive, and the unsettling questions: From where exactly are these wounds transposed? Where do they originate? Whose faces have seen such violence?

\section{Transposing Wounds-RAMT II}

The technique of transposition is remarkably explicit in Kærn's portrait series. Some of the politicians look dreamy and content, others tired and concerned, but none of the faces display the utter horror, pain and distortion that the facial wounding dictate. There is a disconnection between the corporal marks of extreme violence and the faces: the indexicality of the wound is revoked. ${ }^{8}$ Thus, although we may feel outrage and indignation at the transgressive symbolic gesture, we do not really feel sorry for the unaffected politicians, since the strategy of 'fictionalized' wounding is easily decoded. There is no pretence of a direct corpo-reality, and no sympathy or compassion is invoked on behalf of the politicians. The faces maintain a purely political-symbolic function, and do not convey the portrayed Other as a vulnerable, suffering human being.

However, it seems insufficient to conclude that the portraits pertain simply to the workings of representational democracy, and that no sense of human suffering is conveyed by the series. This is attributable to the fact that, while the wounding is fictionalized, the wounds themselves retain a recalcitrant sense of displaced indexicality and corporeality. Hence, the bleeding, open wounds relentlessly raise the nagging question of transference and point beyond (Butler 2006) the portrayed faces to conjure up the bloody realities of the distant wars Denmark is waging. Returning to Butler's point about representational 'failure' as the premise of conveying the vulnerability of the Other, we may consider the portraits as openly and knowingly failing. The portrayed faces do not and cannot capture and represent a distant suffering Other. However, the transposed wounds perpetually attest to this failure, and thus convey a 
sense of human suffering. Hence, the explicitly 'failed' wounding of the politicians paradoxically evokes the very real effects of the political decisions allowing such wounding in other settings, and of other faces. Thus, we are left with the question of who is actually 'given a face' in these portraits, when the faces depicted do not convey a direct encounter with a suffering, vulnerable Other, but the facial wounds nevertheless point beyond the represented faces as a residue of human suffering and vulnerability.

\section{FACING VETERANS OF WAR-RAMT II}

In light of the contemporary Danish focus on the wounded veteran, and Kxrn's own statement that she drew the portraits at the behest of a Danish veteran and artist with PTSD in order to draw more attention to wounded soldiers (Rosenvinge and Villemoes 2013), the answer seems obvious: the wounds of war conjure the wounded faces of the nation's veterans. And, indeed, the absent presences of soldiers haunt the portrait series in a number of ways.

Turning to the margins of the portrait series, a rather banal observation may suggest this: each portrait is named after the minister depicted. Although this is standard in the portrait genre, it is worth noting that Kærn has chosen to deploy first names only in most titles, so that the portraits of the three former Prime Ministers are called Anders, Helle and Lars. $^{9}$ This may be read as a continuation of the dismantling of the gap between politicians and private citizens, and the redistribution of a sense of responsibility in civil society. However, to a Danish art audience, these first name titles also bring to mind the 'war paintings' by Danish artist John Kørner. For his War Problems series (2008-2009), Kørner produced more than 20 large-scale paintings that depict various scenes from the war-stricken Afghan landscape. Kørner was one of the first artists to examine contemporary Danish warfare from an aesthetic standpoint, and, to the Danish public, his enormous, brightly-coloured and airy depictions of war are probably still some of the best-known examples of war art. In 2008-2010, the paintings received extensive publicity: it was announced that Kørner created one painting for each soldier killed in Afghanistan (however, he never did; roughly half the paintings have been made so far), and the Crown Prince and Princess commissioned him to create a special edition mural of such a war painting in their private residence. However, the names included in the series' titles drew 
particular attention: each painting has a title such as, Mark, Jacob under the horse, and Thomas. These are the names of Danish soldiers killed while deployed in Afghanistan. The very real use of the deceased soldiers' names clashed with the paintings' almost abstract style, and the fact that Kørner had never been to Afghanistan himself and consciously avoided extensive research into the war. Hence, the scenes depicted are not artistic reproductions of the fatal situations leading to the soldiers' deaths, but the artist's aesthetic vision of Afghan landscapes and Danish warfare. However, his use of actual soldiers' names creates a haunting reality effect, and conjures up the very real, fatal consequences of remote warfare in the midst of the abstract, beautiful scenes. Hence, Kxrn taps into this unsettling use of the first name in contemporary Danish visual art: the first names in the titles of the politicians' portraits continue to conjure up the names of the fatally wounded soldiers that haunt War Problems. Anders, Helle and Lars call for the absent presences of Mark, Thomas and Jacob under the horse, the deceased soldiers. However, at the same time Kærn also displaces and renegotiates Kørner's use of the referentiality of the name: in her portraits, what haunts us is not the reality effect of the names as such, the identities of the very real politicians, but the fictionalized transposition of the presumably equally real, gaping facial wounds, which call the wounded soldiers to mind.

Kærn's deliberate use of materials, form and genre enhance this haunting presence of wounded soldiers in the politicians' portraits. As mentioned, each portrait has been drawn with coloured pencil on brownish cartridge paper (Rosenvinge and Villemoes 2013). The colours are subdued and washed out, leaving the wounded faces almost translucent at some points, allowing the brown cartridge paper to show through. As cartridge paper has historically been used in ammunition as paper cartridges for firearms, a long history of violence and war is invoked solely by the materiality of the portraits.

When combined with the portrait genre, the brownish colour of the paper also recalls the sepia hue of old photographs: portraits of uniformed, long-dead young men on bureaus in family homes. Owing to the politicians' facial disfigurement, one particular medico-photographic genre comes to mind: the photographic documentation of the gueules cassées [broken faces] of World War I. The term 'gueules cassées' was coined in 1921 by a French veteran to designate those soldiers who, like himself, survived violence to the head, and had to live with serious facial disfigurements (Pichel 2017). The 'broken' faces of these veterans were 
subject to prolonged documentation and photographing in hospital settings, to improve and disseminate medical knowledge. The photographs were "completely focused on the face of the patient, who was sitting in an unrecognizable space still wearing the military uniform or, sometimes, the ward clothes. This kind of portrait [...] aimed to focus the viewer's attention on the facial damage' (Pichel 2017, pp. 88-89). The formal similarity to the politicians portrayed 'uniformed' in dark suits against a neutral background is striking. However, importantly, Kærn's portraits are still bleeding. There is no attempt to stitch together and heal the wounds, reconstruct the face and close the door on the past. Instead, 'the past lives in the very wounds that remain open in the present' (Ahmed 2014, p. 33, my italics). Hence, Kærn's portraits are in conversation with a visual genre invented and conditioned by modern warfare and medical research. The wounded politicians are drawn against a material backdrop of cartridges, facial disfigurement, the pursuit of medical progress, and violence. However, instead of sealing and healing this history of violence, Kærn leaves the wounds open and the blood streaming. This may be read as a way of avoiding the fetishization of the veterans' wounds (Ahmed 2014), observable in public discourse, but when we conclude this chapter, we will return to the hauntological potential of the streaming blood.

The portrait series works by imposing a visually evident vulnerability on the politicians' bodies, in order implicitly to evoke-through a number of more or less explicit traces-the vulnerability of the bodies they are responsible for deploying to war zones: Danish soldiers. However, in the following section, we will examine how the portraits not only convey an encounter with this veteran Other, but also with the distant suffering Other of contemporary, remote warfare.

\section{FACING THE OTHER-RAMT I}

RAMT is a title Kærn has used before. In 2010, she produced a portrait series named RAMT. Sarrede danske soldater $i$ Helmand, which was a part of the 2012 exhibition Krig i kunsten [War in the arts, my translation] at The Museum of National History. In all formal aspects, these portraits resemble the later series that bears the same title: they are characterized by subdued, neutral colours; they are made with coloured pencil on brownish paper; and they depict seriously wounded faces in a medium close-up framing. The weaving together of titles, style and format calls on us to read the two series together. They are embroidered into and 
haunt each other. However, in the 'original' series, all those portrayed are purportedly unknown Danish soldiers, not prominent politicians. Moreover, we do not question the indexicality of the wounds in these faces: the exhausted gaze, the raised eyebrows, the chapped lips and the bloodied bandage all confirm the pain and suffering of the soldiers depicted. Hence, the portraits of this earlier series of wounded soldiers persist as a scar, a watermark, a haunting presence beneath the portraits of the politicians. Thus, our reading seems confirmed. The gaping wounds in the faces of the politicians point beyond, to these bleeding portraits, to the faces of wounded Danish soldiers. What is haunting and unsettling in the latter series is the wounding and death of the soldiers represented in the original portrait series. Thus, it may be said that Kærn's two portrait series ultimately sustain the focus and investment in the wounded veteran body as identified in media and political discourse. Even if the portraits complicate political representation and responsibility, and reject the fetishization of the war wound, they nevertheless pertain to domestic victims of war. Hence, the wounded, suffering, non-Western Other seemingly disappears from view once again. However, one may wonder, why do all the soldiers depicted have piercing blue eyes?

When examining the portraits of the wounded soldiers, their azure blue eyes and almost orange hair and beards strike you as odd. You may want to explain it away as a trait of nationality and 'Nordic-ness': these young Danish men simply have a typical Nordic appearance. This, however, seems unsatisfactory: in the midst of the neutral, sepia-like hue of the portraits, these two colours - orange and blue - stand out in an almost shrilling way. Why these insistent blue eyes, why this unnatural yelloworange hair, why this overdoing of Nordic traits? The answer, once again, is given in the margins, in the captions that often accompany the reproductions of the drawings: the wounded soldiers are, in fact, not Danes, but local, wounded Afghans 'made Danish' by changing their hair and eye colour (Figs. 13.1 and 13.2). ${ }^{10}$

One article explains this 'Nordification' as being due to the artist's lack of access to pictures of wounded Danish soldiers, leaving her with no other models than wounded Afghans (Rosenvinge and Villemoes 2013). This seems implausible, because, as Brigitte Refslund Sørensen suggests, wounded Danish soldiers have been rather visible in Danish media, and pictures of Danish and/or other Western soldiers may be accessed online; for example, in helmet camera footage on YouTube. However, we could accept this explanation, until we catch another glimpse of the odd orange 


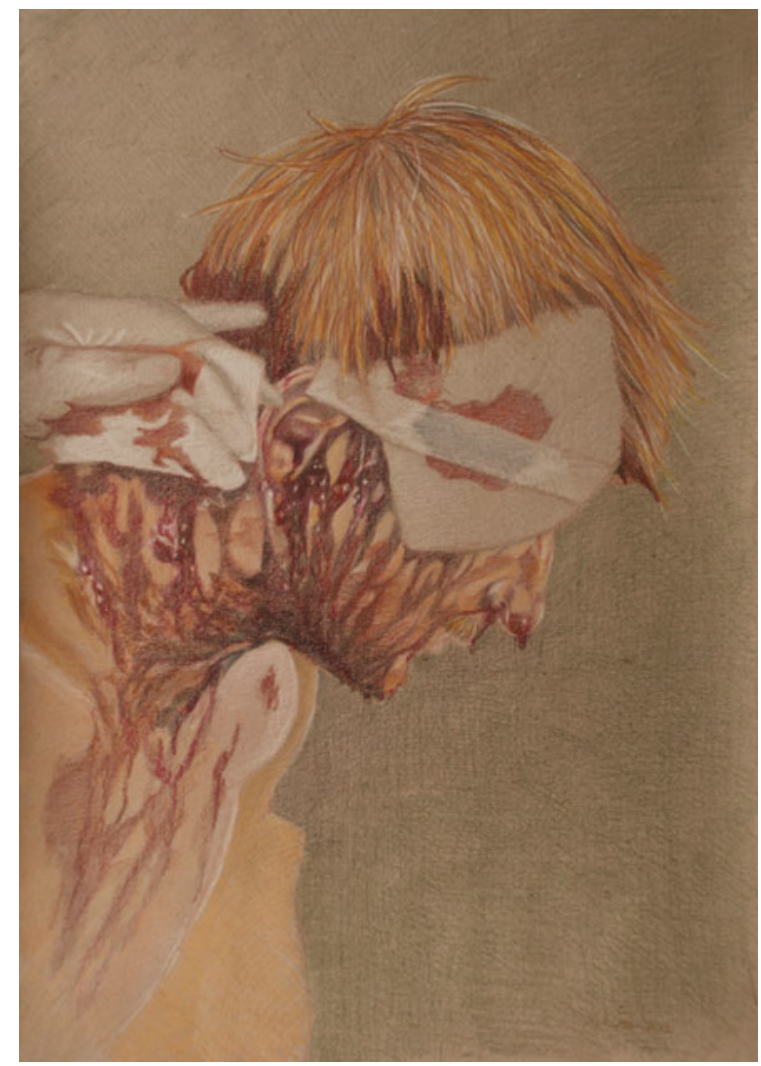

Fig. 13.1 By (C) Simone Aaberg Kærn, 2010, coloured pencil on rough paper. The 'soldiers' are wounded Afghans who have been made 'Danish' by changing their eye and hair colour

beards. Surely, an accomplished artist such as Kærn-educated at Goldsmiths and The Royal Academy of Fine Arts in Copenhagen-could have implemented 'Nordicness' in a less shrill, off-putting manner?

Thus, we have to take Kærn's overdoing at face value, and ask why the portraits insist on the shrill orange hair and the chilling blue eyes in the hybridized Afghan-Danish faces. I suggest that the blatancy of the transformation of the faces is-like the transposed wounds in the politicians' faces - a means of failing at, of undermining, openly and knowingly, the 


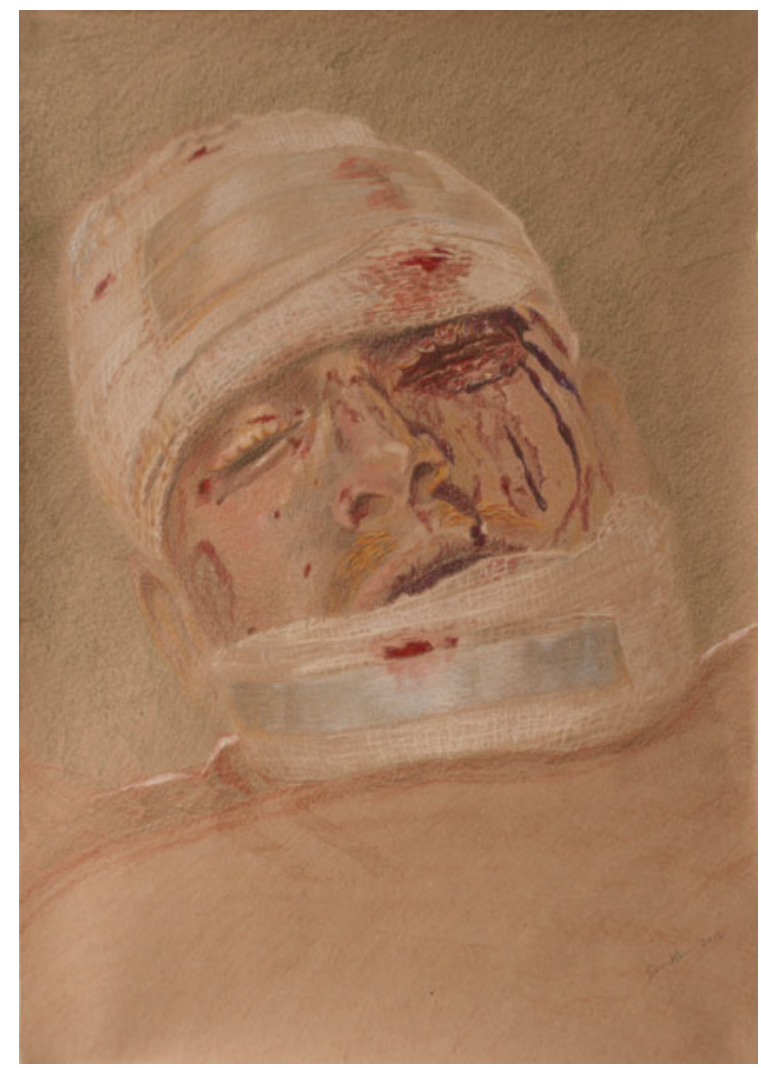

Fig. 13.2 By (C) Simone Aaberg Kærn, 2010, coloured pencil on rough paper. The 'soldiers' are wounded Afghans who have been made 'Danish' by changing their eye and hair colour

act of representation, and, thus, of pointing beyond (Butler 2006) to all that is not captured in the portraits. Hence, although these faces, in contrast to those of the politicians, do indeed explicitly express suffering and convey vulnerability, it is a displaced or distributed suffering and vulnerability that stems not only from the 'portrayed' wounded 'Danish soldiers', but also from the absent-present bodies of Afghans, the civilian, allied and enemy victims of Danish warfare. Thus, through its striking hybridization of faces and the explicit 'failure' of representation, the RAMT series 
actually conveys an encounter with the suffering Other of contemporary, remote warfare. Retract the orange beard, the uniform, and the blue tint of the eyes, and we uncover and encounter the suffering face of a distant, unknown Other, wounded by war.

When bringing Butler's thinking to bear on Kærn's works, we can see how the portrait series' layering of faces and representational 'glitches' is a way of renegotiating the distribution of the in/visibilities of different victims of war in Danish public discourse. As Kærn employs the hypervisibility of Danish wounded veterans, she also undermines and renegotiates the national framing of lives, and suffering of war, through a technique of folding, layering and haunting. In a haunting encounter with the absentpresent Other of distant warfare, we are faced with the vulnerability of Danish and Afghan, combatant and non-combatant, Western and nonWestern bodies alike. Ultimately, the shared human vulnerability evoked by the portraits works as a call for non-violence when facing these distant, suffering human beings.

\section{Being Haunted-the Political Potential of Streaming Blood}

There is one final trace of blood streaming down the layered faces that we need to address. To grasp this last bloody complication, I wish to weave a hauntological thread into the Butlerian analysis. ${ }^{11}$ In Spectres de Marx (1993), Derrida, who, like Butler, works with a Levinasian ethics of encounter, suggests that we will have to learn to live with ghosts. Not in order to rid ourselves of them through an act of exorcism, but to cultivate a position of radical openness and responsibility. 'No justice [...] seems possible or thinkable without the principle of some responsibility, beyond all living present, within that which disjoins the living present, before the ghosts of those who are not yet born or who are already dead' (Derrida 2006, p. xviii). Derrida's notion of haunting is not solely a matter of violent pasts living on, but also of possible unknown futures to come (back). By way of 'an affirmative thinking of the messianic and emancipatory promise as promise' (Derrida 2006, p. 94), Derrida couples the ghost with the event of the 'future-to-come': democracy and justice (always, perpetually) to come. Thus, Derrida's hauntology spectralizes and radicalizes the relation to the Other of Levinas and Butler. ${ }^{12}$ The haunting encounter becomes more than a way of perceiving a shared human vulnerability - it is a means of interrogating the way to live 'more justly' 
(Derrida 2006, p. xviii), of assuming ethical and political responsibility for the ghosts of past lives lived, and the lives to come, the spectres to which we are ethically bound.

Returning to the portraits, I contend that the perpetually bleeding wounds of war comprise such a haunting. Looking at the streaks of blood streaming down cheeks and foreheads, you may feel an immediate urge to wash the faces and bandage the wounds, to clean and to heal. However, Kærn's insistence on the open wound hinders us from stitching together, looking forward, and moving on: these bleeding wounds haunt us with unsettling questions about the logics of violence, and the past, present, and future production of war-wounded bodies. Certainly, the portraits' gore is also simply a way of catching and holding the eye. However, Kxrn probably could have attained the same reaction by portraying faces severely scarred by war. The temporality of such depictions, however, would be radically changed: the scar pertains to the past, whereas the perpetually bleeding wound is of the past, the present now, and the future moments of encounter. As such, the streaming blood is not only an indexical trace of violence overcome, but also of the perpetual wounding and bleeding of bodies in present and future wars. It inscribes an immediacy or ongoing-ness that the scar does not. Hence, the portrait series do not convey only a layered ethical encounter with the suffering human Other of distant wars, they also conjure up the violent injustices of contemporary Western warfare, and question the ongoing real-time infliction of such war wounds. The streaming blood haunts us as a remainder of violence-past, but also raises political questions of the future-to-come. The open wounds forge a political potential in the portrait series, and impel us to stop the wounding of bodies, to engage in other forms of global relations, and to cultivate other ways of living together.

\section{Notes}

1. According to the Prime Minister's Office's archive of speeches, the Prime Minister has given an annual speech at the national flag-flying day event in Copenhagen since 2009-except in 2014 and 2016, when other governmental representatives gave the speech. This means that the liberal Prime Minister Lars Løkke Rasmussen (in office from 2009-2011 and from 2015 to 2019) has given the speech six times, and Social Democrat Helle Thorning-Schmidt (2011-2015) has given it twice. These eight speeches given on 5 September by Prime Ministers Lars Løkke Rasmussen 
and Helle Thorning-Schmidt form the basis of this analysis. In line with the increasing national focus on veterans, since 2010 it has been customary for the Prime Minister to address the veterans and/or veterans' concerns in the speech.

2. Technically, the term 'palimpsest' is used to designate a manuscript where an original text has been partly erased and overwritten by another text, so that two or more texts occupy the same page. However, the term has been adopted to indicate a theoretical prism for investigating relationality, layering, spectrality, and reworking, for example, by Andreas Huyssen in Urban Pasts (2003), and by Gerard Genette in his seminal work on interor trans-textuality, Palimpsestes (1997). A palimpsestic mode of reading registers temporal complexities, hauntings and traces of histories, and proceeds by uncovering layers of presence in a given work. In this chapter, 'text' is understood as any cultural signifying practice or artefact.

3. On a national flag-flying day, state authorities have to display the Danish flag to mark the day as a day 'of particular national importance' (Christensen 2015, p. 352).

4. I have translated all newspaper headlines.

5. 'Ride 4 Rehab' is a national bicycle race for wounded veterans.

6. Also see Rasmussen (2011), on how, paradoxically, the death of Danish soldiers in Afghanistan did not initiate a public debate on the strategies and goals of the war, but came to be seen as a confirmation of the moral righteousness of the mission (Rasmussen 2011, pp. 98-102).

7. From a contemporary point of view, it is striking that no members of the influential right-wing Danish People's Party have been portrayed and 'wounded'. However, this attests to the party's preference for an oppositional role and avoidance of ministerial power, rather than to a political bias in the artwork.

8. In this way, the portraits differ from the portrait series Det virtuelle teskehold (2009) ['The virtual gang of goons', my translation] by Danish painter Benny Vigan Madsen. In creating her portrait series, Kærn has been accused of imitating, and even plagiarizing, Madsen's series of five paintings depicting Danish politicians posing as boxers with bruised faces and clenched fists. These accusations only added to the intensity of the media debate on Kxrn's drawings, and even led Madsen to produce two additional paintings for his series, depicting himself and Kxrn as bruised boxers. However, in contrast to Madsen's efforts at realism and accuracy, Kxrn makes the act of transposing explicit, as she insists on the overt clash of war wounds and unaffected Danish politicians. From the beginning, the portraits were conditioned by this clash: Kærn reportedly started by painting an accurate portrait of each politician, and then subsequently added the war wounds (Rosenvinge and Villemoes 2013). 
9. However, the portrait of former Defence Minister Søren Gade is titled 'Gade', and thus employs his last name.

10. It has not been possible to track down the exhibition catalogue, or the original captions used for the 2012 exhibition. Thus, it is impossible to say whether this key information was accessible to the audience at the exhibition. However, on her website Kærn (2018) displays these portraits, along with the following caption: 'by Simone Aaberg Kærn 2010, coloured pencil on coarse paper. "The soldier" is a wounded Afghan, who has been “made Danish” by changing his eye and hair colour' (my translation).

11. In her later works, Butler touches on haunting a few times, as a prism for the spectral existence of the excluded, muted lives lived 'outside' of cultural, visual and discursive 'frames' (Butler 2009, 2006). As such, the Butlerian notion of haunting also pertains to the framing of lives as un/grievable and in/visible. However, as I see it, she tames the ghost, as it is continually traced back to safe ontological ground in the human Other. In this notion of haunting, there is a certainty that the deconstructive hauntology radically undoes.

12. Importantly, Derrida introduces a 'visor effect', so that the ghost may always see you, but you may never see the ghost. Thus, the face of the Levinasian encounter is hidden, and the otherness of the Other is radicalized (Derrida 2006; Rösing 2009).

\section{ReferenCes}

Ahmed, S. (2014). The Cultural Politics of Emotion (2nd ed.). Edinburgh: Edinburgh University Press.

Butler, J. (2006). Precarious Life: The Powers of Mourning and Violence. New York: Verso.

Butler, J. (2009). Frames of War: When Is Life Grievable?. New York: Verso.

Christensen, T. D. (2015). The figure of the soldier: Discourses of indisputability and heroism in a new Danish commemorative practice. Journal of War \& Culture Studies, 8(4), 347-363.

Derrida, J. (2006). Spectres of Marx. New York: Routledge.

Elmelund, R. (2013, March 20). En symbolsk terroraktion. Information.

Genette, G. (1997). Palimpsests: Literature in the Second Degree. Lincoln: University of Nebraska Press.

Huyssen, A. (2003). Present Pasts: Urban Palimpsests and the Politics of Memory. Stanford: Stanford University Press.

Juergensmeyer, M. (2003). Terror in the Mind of God: The Global Rise of Religious Violence. Berkeley: University of California Press.

Kærn, S. A. (2018). Ramt-Soldater, Afghanistan. http://krigogkunst.dk/ ramt-soldater-afghanistan/ Accessed November 26, 2018. 
Lévinas, E. (1996). Totalitet og Uendelighed: Et essay om exterioriteten. Copenhagen: Hans Reitzels Forlag.

Lidegaard, B. (2018). Danmark $i$ krig. Aarhus: Aarhus Universitetsforlag.

Lyngberg, C. (2015, January 6) Overblik: De mest opsigtsvækkende politisk motiverede overfald. Politiken.

McLoughlin, K. (2018). Veteran Poetics: British Literature in the Age of Mass Warfare, 1790-2015. Cambridge: Cambridge University Press.

Mortensen, M. (2008). Den digitale slagmark: Danske soldaters krigsvideoer fra Afghanistan. Kosmorama, 241, 25-35.

Pedersen, L. N., \& Westh, A. (2010, June 20). Det mentale minefelt. Jyllands-Posten.

Pedersen, T. R. (2017). Soldierly Becomings: A Grunt Ethnography of Denmark's New 'Warrior Generation' (Doctoral dissertation). Department of Anthropology, Faculty of Social Sciences, University of Copenhagen, Copenhagen.

Pichel, B. (2017). Les Gueles Cassées: photography and the making of disfigurement. Journal of War \& Culture Studies, 10(1), 82-99.

Rahbek, B., \& Rix, L. (2013, March 20). I krig og kunst gælder alle kneb. Berlingske.

Rasmussen, L. L. (2018). Statsminister Lars Løkkes tale ved Flagdagen for udsendte soldater den 5 September 2018. http://www.stm.dk/_p_14724.html Accessed October 4, 2018.

Rasmussen, M. V. (2011). Den gode krig. København: Gyldendal.

Rosenvinge, L., \& Villemoes, S. (2013, April 29). Din minister bløder. Atlas.

Rösing, L. M. (2009). Den sene Derrida, eller: Er Claus Beck-Nielsen et spøgelse? Passage, 61, 75-89.

Sangild, T. (2016). Hvordan maler man den danske krigsindsats? Zetland. https://www.zetland.dk/historie/s8dQBmNm-ae2KvJdE-7fa28 Accessed November 29, 2018.

SFI. (2012). Soldater efter udsendelse: En spørgeskemaundersøgelse. København: SFI, Det National Forskningscenter for Velfærd.

Sørensen, B. R. (2015). Veterans' homecomings: Secrecy and postdeployment social becoming. Current Anthropology, 56(12), 231-240.

Sørensen, B. R. (2017). Public commemorations of Danish soldiers: Monuments, memorials, and tombstones. Critical Military Studies, 3(1), 27-49.

Sørensen, B. R., \& Pedersen, T. (2012). Hjemkomstparader for Danske Soldater. Slagmark, 63, 31-46.

Veterancenteret. (2016). Selvmord blandt veteraner: 1992-2014. Ringsted: Veterancenteret.

Wivel, A. (2013). Danmarks militære aktivisme. In K. S. Kristensen (Ed.), Danmark $i$ krig: Demokrati, politik og strategi $i$ den militere aktivisme (pp. 27-52). København: Jurist-og Økonomiforbundets Forlag. 
Open Access This chapter is licensed under the terms of the Creative Commons Attribution 4.0 International License (http://creativecommons.org/licenses/ by $/ 4.0 /$ ), which permits use, sharing, adaptation, distribution and reproduction in any medium or format, as long as you give appropriate credit to the original author(s) and the source, provide a link to the Creative Commons license and indicate if changes were made.

The images or other third party material in this chapter are included in the chapter's Creative Commons license, unless indicated otherwise in a credit line to the material. If material is not included in the chapter's Creative Commons license and your intended use is not permitted by statutory regulation or exceeds the permitted use, you will need to obtain permission directly from the copyright holder.

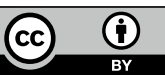

